\title{
SARS-CoV-2 infection and transmission in school settings during the second COVID-19 wave: a cross- sectional study, Berlin, Germany, November 2020
}

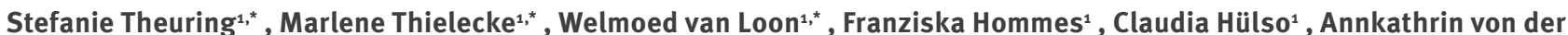
Haar $^{1}$, Jennifer Körner ${ }^{1}$, Michael Schmidt ${ }^{2}$, Falko Böhringer ${ }^{3}$, Marcus A Mall ${ }^{4}$, Alexander Rosen ${ }^{4}$, Christof von Kalle ${ }^{5}$, Valerie Kirchberger $^{6}$, Tobias Kurth $^{7}$, Joachim Seybold ${ }^{6}$, Frank P Mockenhaupt ${ }^{1}$, BECOSS Study Group ${ }^{8}$

1. Institute of Tropical Medicine and International Health, Charité - Universitätsmedizin Berlin, corporate member of Freie Universität Berlin and Humboldt-Universität zu Berlin, Berlin, Germany

2. German Red Cross Blood Transfusion Service, Frankfurt, Germany

3. Labor Berlin - Charité Vivantes Services GmbH, Berlin, Germany

4. Department of Pediatric Pulmonology, Immunology and Critical Care Medicine, Charité - Universitätsmedizin Berlin, corporate member of Freie Universität Berlin and Humboldt-Universität zu Berlin, Berlin, Germany

5. Clinical Study Center, Charité - Universitätsmedizin Berlin, corporate member of Freie Universität Berlin and HumboldtUniversität zu Berlin, Berlin, Germany

6. Medical Directorate, Charité - Universitätsmedizin Berlin, corporate member of Freie Universität Berlin and HumboldtUniversität zu Berlin, Berlin, Germany

7. Institute of Public Health, Charité - Universitätsmedizin Berlin, corporate member of Freie Universität Berlin and HumboldtUniversität zu Berlin, Berlin, Germany

8. The members of the BECOSS study group are listed under Investigators

These authors contributed equally and share first authorship.

Correspondence: Frank P Mockenhaupt (teststrategie@charite.de)

Citation style for this article:

Theuring Stefanie, Thielecke Marlene, van Loon Welmoed, Hommes Franziska, Hülso Claudia, von der Haar Annkathrin, Körner Jennifer, Schmidt Michael,

Böhringer Falko, Mall Marcus A, Rosen Alexander, von Kalle Christof, Kirchberger Valerie, Kurth Tobias, Seybold Joachim, Mockenhaupt Frank P, BECOSS Study

Group. SARS-CoV-2 infection and transmission in school settings during the second COVID-19 wave: a cross-sectional study, Berlin, Germany, November 2020. Euro Surveill. 2021;26(34): pii=2100184. https://doi.org/10.2807/1560-7917.ES.2021.26.34.2100184

Background: School attendance during the COVID19 pandemic is intensely debated. Aim: In November 2020, we assessed SARS-CoV-2 infections and seroreactivity in 24 randomly selected school classes and connected households in Berlin, Germany. Methods: We collected oro-nasopharyngeal swabs and blood samples, examining SARS-CoV-2 infection and IgG antibodies by RT-PCR and ELISA. Household members self-swabbed. We assessed individual and institutional prevention measures. Classes with SARS-CoV-2 infection and connected households were retested after 1 week. Results: We examined 1,119 participants, including 177 primary and 175 secondary school students, 142 staff and 625 household members. SARSCoV-2 infection occurred in eight classes, affecting each 1-2 individuals. Infection prevalence was $2.7 \%$ (95\% confidence interval (Cl): 1.2-5.0; 9/338), 1.4\% (95\% Cl: $0.2-5.1 ; 2 / 140$ ), and 2.3\% (95\% Cl: 1.3-3.8; $14 / 611)$ among students, staff and household members. Six of nine infected students were asymptomatic at testing. We detected IgG antibodies in $2.0 \%$ (95\%Cl: $0.8-4.1 ; 7 / 347), 1.4 \%$ (95\% Cl: $0.2-5.0$; 2/141) and 1.4\% (95\% Cl: 0.6-2.7; 8/576). Prevalence increased with inconsistent facemask-use in school, walking to school, and case-contacts outside school. For three of nine households with infection(s), origin in school seemed possible. After 1 week, no schoolrelated secondary infections appeared in affected classes; the attack rate in connected households was
$1.1 \%$. Conclusion: School attendance under rigorously implemented preventive measures seems reasonable. Balancing risks and benefits of school closures need to consider possible spill-over infection into households. Deeper insight is required into the infection risks due to being a schoolchild vs attending school.

\section{Introduction}

In the coronavirus disease (COVID-19) pandemic, schooling takes a central role in the public debate. The focus is on whether schools are safe to attend, whether children, adolescents, and/or schools are relevant sources of community infections and whether school operation should be maintained, modified, or suspended [1]. Compared with adults, SARS-CoV-2 infections in children tend to take a milder or asymptomatic course, while to date, contagiousness still is debated $[2,3]$. However, children and adolescents temporarily had high incidences during autumn 2020 $[4,5]$. Modelling suggests that closure of educational facilities could notably limit overall transmission [6]. Nevertheless, there still is insufficient evidence as to whether schools actually drive the pandemic, or rather mirror it $[7,8]$. Observational studies on the association of school closures with community transmission have yielded inconsistent results according to a systematic review, ranging from none to substantial reduction in transmission [9]. When considering infection risks, a distinction needs to be made between 
school as a physical venue, students and age-typical, contextual whereabouts, e.g. public transport or afterschool meetings. Limited data suggest that schools are not high-risk settings for SARS-CoV-2 transmission between students and/or staff $[2,10]$. On the contrary, there is evidence that school attendance itself is not a risk factor, whereas inconsistent mask use in school, contact with COVID-19 cases and gatherings outside the household are risk factors [11]. Therefore, risks need to be balanced against the detrimental impact school closures have on children and on societies' health, social equality, workforce and economy $[12,13]$.

Germany experienced a second pandemic wave in September 2020 and implemented a countrywide lockdown including school closures on 16 December 2020. During the peak of the second wave, we assessed SARS-CoV-2 infection and transmission in Berlin schools among schoolchildren, staff and connected household members and estimated the extent of secondary infections arising from the school context.

\section{Methods}

Study design, setting and participants

This was a cross-sectional analysis of a longitudinal study among students and school staff, including teachers, educators and facility staff, from 24 schools in Berlin (one class per school) and related household members. A first round of examinations of the same students and school staff had taken place in June 2020 [14]. The present second round was conducted between 2 and 16 November 2020. During that time, SARS-CoV-2 transmission in Berlin was comparatively high: 14,514 cases were recorded, and the 7-day incidence was 185-210/100,000 inhabitants [15]; the 7-day incidence in Berlin was highest in school-aged children of 10-19-year-olds (Figure). For the random selection of schools, the 12 city districts were divided into three socioeconomical strata [16]. In each stratum, two districts were randomly selected, and within these, two primary and two secondary schools. Three schools unable to participate were replaced by randomly resampled substitutes. Classes were selected among grades $3-5$ (8-12 year-olds) and 9-11 (13-17 year-olds). We aimed to examine 20 students per class

\section{FIGURE}

7 -day incidence of recorded SARS-CoV-2 infections according to age groups in Berlin, Germany, November 2020 $(\mathrm{n}=98,461)$

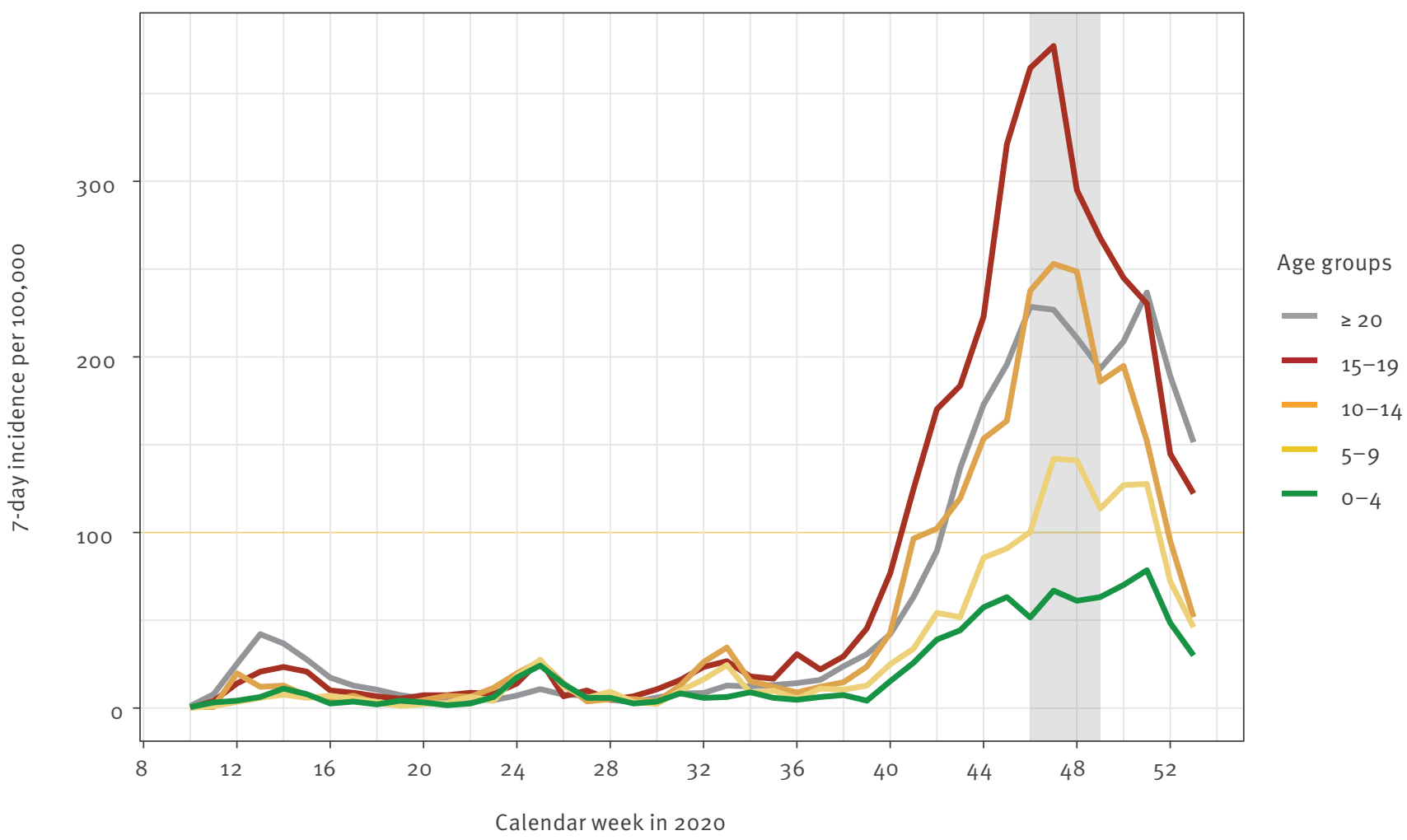

SARS-CoV-2: severe acute respiratory syndrome coronavirus 2.

Study period indicated by grey shading. Data on PCR-confirmed SARS-CoV-2 infections, notified to local health authorities.

Source: Regional Office for Health and Social Affairs Berlin (LaGeSo) COVID-19 in Berlin, distribution in the districts-complete overview. https://daten.berlin.de/datensaetze/covid-19-berlin-verteilung-den-bezirken-gesamt\%C3\%BCbersicht (accessed: 24 October 2020). 
and up to 10 members of staff. In the first round in June, the proportion of students participating per class was 65\% (range: 13-96). Hereafter, students and staff were considered index participants. In this second round in November, household members of index participants were also invited to participate.

\section{Data collection}

Our study teams visited the schools on a scheduled day. We obtained a brief medical history from each participant and scanned forehead temperature. Fever was defined astemperature $\geq 37.5^{\circ} \mathrm{C}$. Oro-nasopharyngeal swabs (nerbe plus, Winsen/Luhe, Germany) were collected and finger-prick blood samples taken onto filter paper (BioSample Card, Ahlstrom Munksjö, Helsinki, Finland). Household members attended mobile clinics at school for symptom assessment and finger-pricking. They delivered self-collected swabs (oropharynx and nostrils), after having received instructions and swabs (CoronaOne, Berlin, Germany) beforehand. Participants absent due to illness or quarantine were visited at home, usually on the same day as the school visit. SARS-CoV-2 infection was determined by RT-PCR (GFE-Blut, Frankfurt, Germany). For antiSARS-CoV-2-IgG, $4.75 \mathrm{~mm}$ dried blood spot discs were extracted in $250 \mu \mathrm{L}$ buffer, and ELISA was performed on a EUROLabWorkstation (Euroimmun AG, Lübeck, Germany). Where we identified SARS-CoV-2 infection, health authorities were notified, participants received quarantine instructions, and over the following 14 days they were repeatedly interviewed to obtain information on health status and potential infection sources.

Participants completed a child, adolescent, or adult version of an electronic questionnaire 2 days before the study visit. Parameters assessed spanned the preceding 2 weeks if appropriate. These included household composition, signs and symptoms, contacts to SARS-CoV-2-positive persons, hand hygiene, physical distancing and wearing of facemask. Symptoms including sore throat, runny nose, nasal congestion or cough were defined as 'cold-like symptoms'.

Lastly, we documented the school-related implementation of infection prevention and control (IPC) measures recommended by the federal state government Berlin [17]. These included hygiene measures, distancing, absence rules if ill, ventilation, cohorting, staggering of teaching hours, and online teaching. At the time of the second study round, according to governmental regulations, facemask use was obligatory when moving in hallways, but not during class. Schools decided individually if and where they implemented additional measures. We also recorded if persons were quarantined at the time of data collection. A 14-day period of mandatory quarantine was applicable for persons with exposure to an infected individual.

\section{Follow-up data collection}

For classes where SARS-CoV-2 infection was detected, all participating students and staff and their household members self-tested again after 1 week (CoronaOne, Berlin, Germany). For systematic reasons, we retested the entire school sub-cohort (i.e, participating students and teachers), regardless of the type or amount of contact each individual of that class had with the infected person. No retesting was performed if the positive participant was already quarantined at the time of testing, i.e. did not expose classmates or staff.

\section{Data processing and statistical analysis}

Data collection was pseudonymised. On site, data were collected on paper and subsequently entered into the Research Electronic Data Capture (REDCap) tool [18]. Descriptive analyses were segregated for primary and secondary school students, staff and household members.

We compared variables between SARS-CoV-2-infected and -uninfected participants by computing proportions, odds ratios (ORs) and 95\% confidence intervals $(\mathrm{Cl})$. Variables of interest were socioeconomical stratum, contacts to positive cases, wearing of masks within and outside of school, hand washing, and transport to school/work. We used R version 3.6.3 for data analysis [19].

\section{Ethical statement}

The study was reviewed by the Ethics Committee of Charité-Universitätsmedizin Berlin (EA2/091/20). We obtained informed written consent from all participants and legal representatives.

\section{Results}

\section{Participants' characteristics}

We examined 1,119 participants in 24 schools including 177 primary and 175 secondary school students, 142 staff and 625 household members. Of these, 50 participants were housebound due to illness or quarantine and therefore were visited at home, or household members delivered their swabs. Seventeen students and two members of staff had dropped out or withdrawn consent since the first study round in June 2020 (not included in the 1,119 participants). The median age of primary and secondary school students was 11 and 15 years, respectively; half were female (Table 1). Staff were mostly middle-aged and female, with the majority being teachers or educators $(91.2 \%, 114 / 125)$ in addition to facility personnel. Most household members were adults $(73.8 \%, 461 / 625)$. Detailed symptoms are presented in Table 1 . Symptoms within the preceding 2 weeks were reported by $60.2 \%(195 / 324)$ of all index participants, with headache $(37.3 \%, 121 / 324)$, sore throat $(15.7 \%, 51 / 324)$, and rhinorrhoea (14.8\%, 48/324) prevailing. The most common chronic conditions reported were hypertension $(2.6 \%, 13 / 494)$, lung disease $(1.8 \%, 9 / 494)$, and obesity $(1.0 \%, 5 / 494)$. Among household members, the most commonly reported symptoms over the preceding 2 weeks were headache $(30.5 \%, 131 / 429)$, tiredness $(18.6 \%, 80 / 429)$, and rhinorrhoea $(16.8 \%, 72 / 429)$, while the most 
frequently reported chronic conditions included hypertension $(4.6 \%, 29 / 624)$, obesity $(3.7 \%, 23 / 624)$, and lung disease $(2.1 \%, 13 / 624)$.

Valid swabs were available from 347 (98.6\%) students, $142(100 \%)$ staff, and 622 (99.5\%) household members; 22 specimens were lost or did not yield a result. The electronic questionnaires had a response frequency ranging from $54.9 \%(614 / 1,119)$ to $67.7 \%(758 / 1,119)$ for individual items.

\section{Infection prevention and control measures in schools}

All schools reported the implementation of basic IPC measures such as visible signs promoting hand hygiene, providing soap and water in restrooms, and active ventilation/airing of rooms at least three times a day. Nearly half of the schools $(10 / 22)$ had a hygiene commissioner. Most students (20/21 classes) and staff $(22 / 23)$ reportedly adhered to hand hygiene and sneezing etiquette more than half of the time. On average, there were 26 students in each class. Three in four classes (18/24) had fixed teaching groups to prevent mixing among students, but mixing with others outside was still possible in almost all schools (22/24). Students were not supposed to attend school if they had symptoms similar to the common cold (in 19/22 classes). More than half of the classes (13/22) did not provide online teaching. In two-thirds (15/24) of the schools, wearing facemask was not obligatory in the classroom for students or staff, but outside the classroom it was obligatory for almost all schools (22/24).

\section{SARS-CoV-2 infections among students and staff}

One or two cases of SARS-CoV-2 infection were detected in one-third (8/24) of the classes summing up to a total of 10 cases detected during the study (Table 2 ). These included six primary school students (two in one class, no close contact reported), three secondary students (two in one class, no close contact reported), and one secondary school staff member. The resulting prevalence in school was $2.7 \%$ (95\% Cl: 1.2-5.0; 9/338) among students and $0.7 \%$ among staff $(95 \% \mathrm{Cl}$ : $0.0-3.9 ; 1 / 140$ ), excluding one isolated staff member who tested positive but had already tested positive 1

\section{TABLE 1}

Characteristics of study participants and SARS-CoV-2 symptoms, Berlin, Germany, 2-16 November 2020 (n = 1,119 participants)

\begin{tabular}{|c|c|c|c|c|c|c|c|c|c|c|c|c|}
\hline Variable & \multicolumn{3}{|c|}{ Primary school students } & \multicolumn{3}{|c|}{$\begin{array}{l}\text { Secondary school } \\
\text { students }\end{array}$} & \multicolumn{3}{|c|}{ Staff } & \multicolumn{3}{|c|}{ Household members } \\
\hline Number of participants & \multicolumn{3}{|c|}{177} & \multicolumn{3}{|c|}{175} & \multicolumn{3}{|c|}{142} & \multicolumn{3}{|c|}{625} \\
\hline $\begin{array}{l}\text { Age in years (median, } \\
\text { range), } n=1,098\end{array}$ & \multicolumn{3}{|c|}{$11.0(9.0,13.0)$} & \multicolumn{3}{|c|}{$15.0(14.0,18.0)$} & \multicolumn{3}{|c|}{$47.0(28.0,65.0)$} & \multicolumn{3}{|c|}{$42.0(2.0,86.0)$} \\
\hline Sex & Total & $\mathrm{n}$ & $\%$ & Total & $\mathrm{n}$ & $\%$ & Total & $\mathrm{n}$ & $\%$ & Total & $\mathrm{n}$ & $\%$ \\
\hline Male & \multirow{2}{*}{176} & 92 & 52.3 & \multirow{2}{*}{175} & 80 & $45 \cdot 7$ & \multirow{2}{*}{142} & 40 & 28.2 & \multirow{2}{*}{617} & 301 & 48.8 \\
\hline Female & & 84 & 47.7 & & 95 & $54 \cdot 3$ & & 102 & 71.8 & & 316 & 51.2 \\
\hline \multicolumn{13}{|c|}{ Reported symptoms on examination day } \\
\hline Any & 177 & 28 & 15.8 & 174 & 35 & 20.1 & 141 & 30 & 21.3 & 600 & 118 & 19.7 \\
\hline Headache & 177 & 6 & 3.4 & 174 & 15 & 8.6 & 141 & 11 & 7.8 & 600 & 30 & 5.0 \\
\hline Rhinorrhoe $^{a}$ & 177 & 19 & 10.7 & 174 & 14 & 8.0 & 141 & 9 & 6.4 & 600 & 62 & 10.3 \\
\hline Cough & 177 & 6 & 3.4 & 174 & 5 & 2.9 & 141 & 7 & 5.0 & 600 & 36 & 6.0 \\
\hline Sore throat & 177 & 3 & 1.7 & 174 & 9 & 5.2 & 141 & 12 & 8.5 & 600 & 30 & 5.0 \\
\hline Diarrhoea & 177 & 1 & 0.6 & 174 & 2 & 1.1 & 141 & 2 & 1.4 & 600 & 12 & 2.0 \\
\hline Limb pain & 177 & 2 & 1.1 & 174 & 0 & 0 & 141 & 0 & 0 & 600 & 8 & 1.3 \\
\hline Loss of smell or taste & 177 & 0 & 0 & 174 & 0 & 0 & 141 & 0 & 0 & 600 & 9 & 1.5 \\
\hline Feeling feverish & 177 & 3 & 1.7 & 174 & 1 & 0.6 & 141 & 1 & 0.7 & 600 & 7 & 1.2 \\
\hline $\begin{array}{l}\text { Fever } \\
\text { (temperature } \geq 37 \cdot 5^{\circ} \mathrm{C} \text { ), } \\
\text { measured on-site }\end{array}$ & 175 & 3 & 1.7 & 174 & 14 & 8.0 & 140 & 4 & 2.9 & 579 & 18 & 3.1 \\
\hline $\begin{array}{l}\text { Any symptoms in the } \\
\text { preceding } 14 \text { days }\end{array}$ & 93 & 45 & 48.4 & 105 & 64 & 61.0 & 126 & 86 & 68.3 & 429 & 238 & $55 \cdot 5$ \\
\hline $\begin{array}{l}\text { Any self-reported chronic } \\
\text { condition }\end{array}$ & 95 & 6 & 6.3 & 105 & 15 & $14 \cdot 3$ & 125 & 35 & 28.0 & 433 & 99 & 22.9 \\
\hline Regular medication & 95 & 4 & 4.2 & 103 & 11 & 10.7 & 125 & 36 & 28.8 & 432 & 109 & 25.2 \\
\hline SARS-CoV-2 infection & 171 & 6 & 3.5 & 167 & 3 & 1.8 & $140^{\mathrm{a}}$ & 2 & 1.4 & 611 & 14 & 2.3 \\
\hline $\begin{array}{l}\text { Anti-SARS-CoV-2 IgG } \\
\text { positivity }\end{array}$ & 174 & 2 & 1.1 & 173 & 5 & 2.9 & 141 & 2 & 1.4 & 576 & 8 & 1.4 \\
\hline
\end{tabular}

IgG: immunoglobulin G; SARS-CoV-2: severe acute respiratory syndrome coronavirus 2.

a One staff member in quarantine, not attending school. 
week earlier. Seven of the 10 SARS-CoV-2 infected individuals were asymptomatic at testing; while two of the seven were asymptomatic throughout, the other five experienced symptoms before and/or after the test day. None of the positive index participants required hospitalisation.

\section{SARS-CoV-2 infections among household members}

Fourteen members of nine households tested positive during the school-based testing, prevalence, $2.3 \%$ (95\% Cl: $1.3-3.8 ; 14 / 611)$. Nine were adults, two preschool children, and three students at schools not participating in the study. Three family members entered the study with a 4-day delay and tested positive. Three of nine households or parts of them were in quarantine (for 3, 10, and 21 days), of which two households comprised a staff member (one of them tested positive), and in the third one, two household members were positive. From the nine positive households, six had no connection with an infected student or staff in school, whereas three did. For the three positive households with a positive student in school, extensive review could not establish the origin of infection.

Half (7/14) of the household members infected with SARS-CoV-2 reported cold-like symptoms on the test day. Among the asymptomatic individuals, most reported symptoms before or after the test date; one adult was briefly hospitalised (Table 3 ).

TABLE 2

Characteristics of SARS-CoV-2 infections detected in schools, Berlin, Germany, 2-16 November $2020(\mathrm{n}=10)$

\begin{tabular}{|c|c|c|c|c|c|c|c|c|}
\hline $\begin{array}{l}\text { Index } \\
\text { participant's } \\
\text { school type }\end{array}$ & $\begin{array}{l}\text { Social } \\
\text { stratum }^{a}\end{array}$ & Ct value & $\begin{array}{l}\text { Temperature } \\
\geq 37.5^{\circ} \mathrm{C}\end{array}$ & $\begin{array}{l}\text { Reported } \\
\text { symptoms on } \\
\text { test day }\end{array}$ & $\begin{array}{l}\text { Symptoms } \\
\text { before test } \\
\text { day }\end{array}$ & $\begin{array}{c}\text { New } \\
\text { symptoms } \\
\text { after test day }\end{array}$ & $\begin{array}{l}\text { Contact with } \\
\text { a confirmed } \\
\text { or suspected } \\
\text { case in } \\
\text { preceding } 2 \\
\text { weeks }\end{array}$ & $\begin{array}{l}\text { Positive HM } \\
\text { (n/n tested) }\end{array}$ \\
\hline $\begin{array}{l}\text { Primary } \\
\text { school }\end{array}$ & High & 14.1 & 37.6 & $\begin{array}{c}\text { None (but } \\
\text { febrile at } \\
\text { examination) }\end{array}$ & $\begin{array}{c}1 \text { day } \\
\text { before test: } \\
\text { headache }\end{array}$ & $\begin{array}{l}1 \text { day after } \\
\text { test: loss of } \\
\text { smell and } \\
\text { taste }\end{array}$ & $\begin{array}{l}\text { Yes, outside } \\
\text { school }\end{array}$ & Yes (1/1) \\
\hline $\begin{array}{l}\text { Primary } \\
\text { school }\end{array}$ & Low & 18.9 & 36.1 & None & $\begin{array}{l}6 \text { days before } \\
\text { test: elevated } \\
\text { temperature, } \\
\text { headache, } \\
\text { fatigue for } 2 \\
\text { days }\end{array}$ & None & $\begin{array}{l}\text { None stated } \\
\text { (other } \\
\text { positive case } \\
\text { in class) }\end{array}$ & No test result \\
\hline $\begin{array}{l}\text { Primary } \\
\text { school }\end{array}$ & Low & 17.0 & 36.1 & $\begin{array}{l}\text { Headache, } \\
\text { cough }\end{array}$ & $\begin{array}{c}5 \text { days } \\
\text { before test: } \\
\text { headache and } \\
\text { fever for } 2 \\
\text { days }\end{array}$ & None & $\begin{array}{c}\text { None stated } \\
\text { (other } \\
\text { positive case } \\
\text { in class) }\end{array}$ & No $(0 / 3)$ \\
\hline $\begin{array}{l}\text { Primary } \\
\text { school }\end{array}$ & Low & $19 \cdot 5$ & 36.5 & None & $\begin{array}{c}3 \text { days } \\
\text { before test: } \\
\text { headache, } \\
\text { eye pain }\end{array}$ & $\begin{array}{l}4 \text { days after } \\
\text { test: anosmia }\end{array}$ & Yes, at school & Yes $(1 / 3)$ \\
\hline $\begin{array}{l}\text { Primary } \\
\text { school }\end{array}$ & Medium & $29 \cdot 5$ & 36.2 & $\begin{array}{l}\text { Headache, } \\
\text { sore throat }\end{array}$ & None & None & $\begin{array}{l}\text { Yes, outside } \\
\text { of school }\end{array}$ & No $(0 / 1)$ \\
\hline $\begin{array}{l}\text { Primary } \\
\text { school }\end{array}$ & Low & $14 \cdot 7$ & 35.2 & None & None & None & None stated & Yes $(3 / 5)^{b}$ \\
\hline $\begin{array}{l}\text { Secondary } \\
\text { school }\end{array}$ & High & 21.8 & 37.1 & None & None & $\begin{array}{l}7 \text { days after } \\
\text { test: sense of } \\
\text { taste changed }\end{array}$ & No data & Not tested ${ }^{c}$ \\
\hline $\begin{array}{l}\text { Secondary } \\
\text { school }\end{array}$ & Medium & 27.1 & $37 \cdot 4$ & None & $\begin{array}{l}10 \text { days } \\
\text { before test: } \\
\text { cold for } 7 \\
\text { days }\end{array}$ & None & $\begin{array}{l}\text { Yes, at school } \\
\text { and other } \\
\text { positive case } \\
\text { in class }\end{array}$ & Not tested \\
\hline $\begin{array}{l}\text { Secondary } \\
\text { school }\end{array}$ & Medium & $23 \cdot 3$ & 36.6 & None & $\begin{array}{c}7 \text { days before } \\
\text { test: sore } \\
\text { throat }\end{array}$ & None & $\begin{array}{l}\text { None stated } \\
\text { (other } \\
\text { positive case } \\
\text { in class) }\end{array}$ & Not tested \\
\hline $\begin{array}{l}\text { Secondary } \\
\text { School }\end{array}$ & Low & 24.4 & 36.1 & None & None & None & None stated & Not tested \\
\hline
\end{tabular}

Ct: cycle threshold; HM: household member; SARS-CoV-2: severe acute respiratory syndrome coronavirus 2.

a Strata ranking is primarily characterised by indicators of unemployment, state transfer payments and corresponding income, as well as health indicators such as premature and avoidable mortality and tobacco-related serious illnesses [16].

${ }^{b}$ Family members tested 4 days after student.

${ }^{c}$ One family member was not tested but had tested positive elsewhere 8 days earlier. 


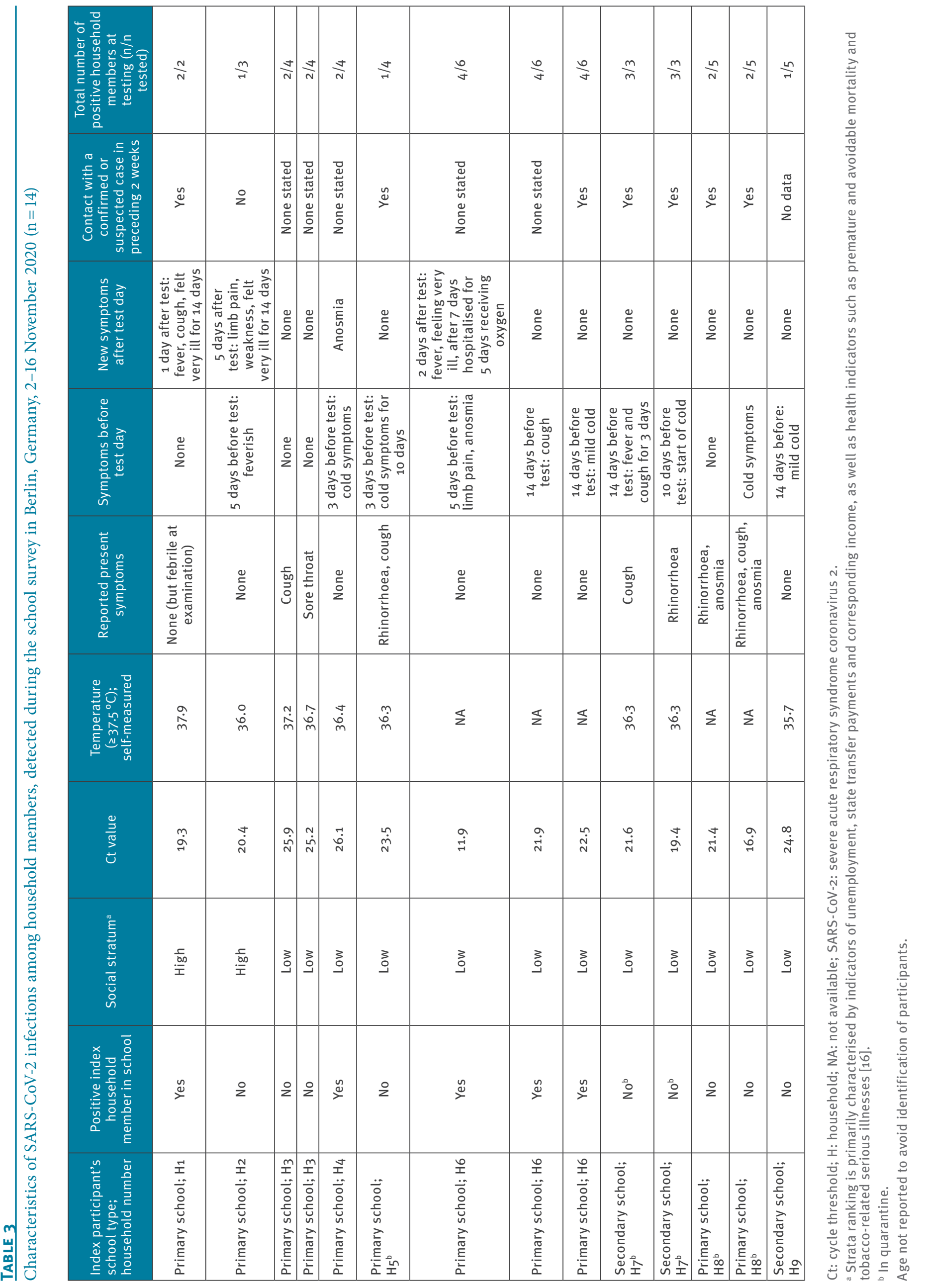




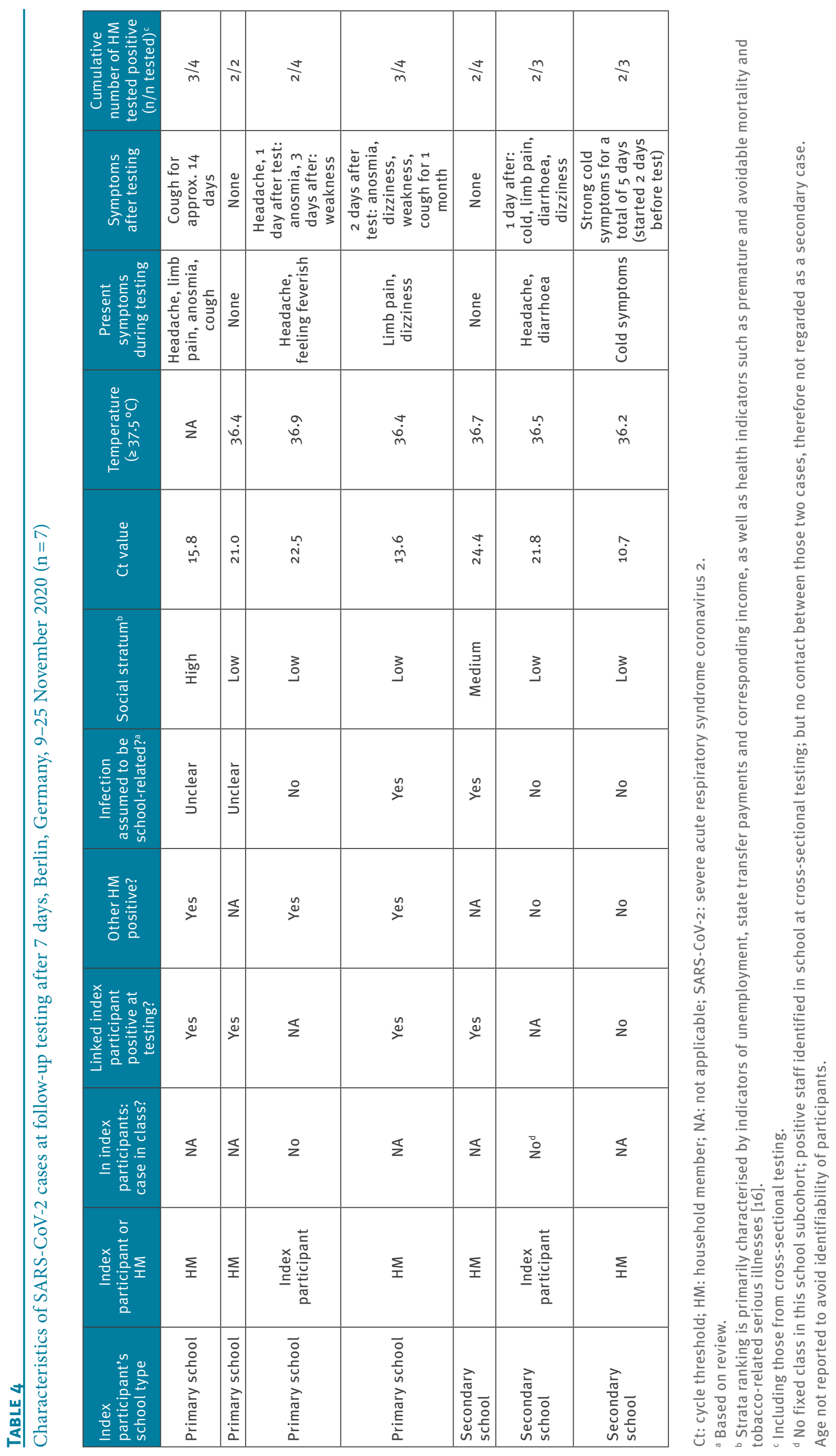


SARS-CoV-2 IgG antibodies

Anti-SARS-CoV-2 IgG antibodies were present in $2.0 \%$ (95\% Cl: $0.8-4.1 ; 7 / 347)$ of students, $1.4 \%(95 \% \mathrm{Cl}$ : $0.2-5.0 ; 2 / 141)$ of staff, and 1.4\% (95\% Cl: $0.6-2.7 \%$; $8 / 576$ ) of household members. Among infected participants, two of 21 showed anti-SARS-CoV-2-lgG, and three of 21 had borderline reactivity. Five presently uninfected index participants who had no antibodies in June 2020 did so in the present study. None was aware of previous infection. Thus, $1.1 \%$ (95\% Cl: $0.4-2.6$;
5/449) of students and staff had been infected with SARS-CoV-2 without noticing.

\section{New SARS-CoV-2 infections at follow-up after 1 week}

Students, staff, and household members connected to eight classes with SARS-CoV-2-positive index participants were retested after 1 week. Students and staff of five of the eight affected classes had been quarantined within a median of 3 days (range: $1-5$ ) after the initial

\section{TABLE 5}

Comparison between SARS-CoV-2 negative and positive index participants, Berlin, Germany, 2-16 November 2020 ( $\mathrm{n}=478$ )

\begin{tabular}{|c|c|c|c|c|c|c|}
\hline \multirow{2}{*}{ Variables } & \multicolumn{2}{|c|}{ Negative, $n=467$} & \multicolumn{2}{|c|}{ Positive, $n=11$} & \multirow{2}{*}{ OR } & \multirow{2}{*}{$95 \% \mathrm{Cl}$} \\
\hline & $\mathrm{n}$ & $\%$ & $n$ & $\%$ & & \\
\hline \multicolumn{7}{|l|}{ Sex } \\
\hline Female & 269 & 97.8 & 6 & 2.2 & 1 & Ref \\
\hline Male & 197 & 97.5 & 5 & 2.5 & 1.14 & $0.27-4.54$ \\
\hline
\end{tabular}

Socioeconomical stratum ${ }^{\text {a }}$

\begin{tabular}{|l|c|c|c|c|c|c|}
\hline High & 193 & 99.0 & 2 & 1.0 & 1 & Ref \\
\hline Medium & 151 & 98.1 & 3 & 1.9 & 1.92 & $0.22-23.18$ \\
\hline Low & 123 & 95.3 & 6 & 4.7 & 4.71 & $0.82-48.18$ \\
\hline Con
\end{tabular}

Contact to suspected or confirmed case at school

\begin{tabular}{|l|c|c|c|c|c|c|}
\hline No & 213 & 96.4 & 8 & 3.6 & 1 & Ref \\
\hline Yes & 92 & 97.9 & 2 & 2.1 & 0.58 & $0.06-2.98$ \\
\hline
\end{tabular}

Contact to suspected or confirmed case outside of school

\begin{tabular}{|c|c|c|c|c|c|c|}
\hline No & 271 & 97.5 & 7 & 2.5 & 1 & Ref \\
\hline Yes & 33 & 91.7 & 3 & 8.3 & 3.52 & $0.56-16.27$ \\
\hline \multicolumn{7}{|c|}{ Mask wearing frequency at school } \\
\hline Often to always & 273 & 98.6 & 4 & 1.4 & 1 & Ref \\
\hline $\begin{array}{l}\text { Never to } \\
\text { sometimes }\end{array}$ & 30 & 85.7 & 5 & $14 \cdot 3$ & 11.38 & $2.28-59.64$ \\
\hline
\end{tabular}

Mask wearing frequency in public

\begin{tabular}{|c|c|c|c|c|c|c|}
\hline Often to always & 299 & 97.4 & 8 & 2.6 & 1 & Ref \\
\hline $\begin{array}{l}\text { Never to } \\
\text { sometimes }\end{array}$ & 5 & 100 & 0 & 0.0 & NA & NA \\
\hline \multicolumn{7}{|c|}{ Hand washing frequency } \\
\hline $0-1$ times & 6 & 85.7 & 1 & 14.3 & 1 & Ref \\
\hline 2-4 times & 92 & 98.9 & 1 & 1.1 & 0.07 & $0.00-5.97$ \\
\hline$\geq 5$ times & 206 & 96.7 & 7 & $3 \cdot 3$ & 0.20 & $0.02-10.70$ \\
\hline
\end{tabular}

Transport to/from school/work

Exclusively by foot

\begin{tabular}{|c|c|c|c|c|c|c|}
\hline No & 259 & 97.7 & 6 & 2.3 & 1 & Ref \\
\hline Yes & 45 & 91.8 & 4 & 8.2 & 3.84 & $0.76-16.83$ \\
\hline \multicolumn{7}{|c|}{ Exclusively by bicycle } \\
\hline No & 227 & 96.6 & 8 & 3.4 & 1 & Ref \\
\hline Yes & 77 & 97.5 & 2 & 2.5 & 0.74 & $0.07-3.81$ \\
\hline \multicolumn{7}{|c|}{ Exclusively by car } \\
\hline No & 249 & 96.1 & 10 & 3.9 & 1 & Ref \\
\hline Yes & 55 & 100 & 0 & 0.0 & $\mathrm{NA}$ & NA \\
\hline \multicolumn{7}{|c|}{ By public transport (exclusively, or in combination with other means of transport) } \\
\hline No & 206 & 97.2 & 6 & 2.8 & 1 & Ref \\
\hline Yes & 98 & 96.1 & 4 & 3.9 & 1.40 & $0.28-6.06$ \\
\hline
\end{tabular}

Cl: confidence interval; NA: not applicable; OR: odds ratio; Ref: reference; SARS-CoV-2: severe acute respiratory syndrome coronavirus 2. a Strata ranking is primarily characterised by indicators of unemployment, state transfer payments and corresponding income, as well as health indicators such as premature and avoidable mortality and tobacco-related serious illnesses [16]. 
test day. In three schools, only close contacts were quarantined. Among 381 tested individuals (who had tested negative or not tested at baseline), seven (1.8\%) new infections were detected at retesting. Of note, no school-related infection of students or staff was observed at retesting. Although two index participants tested positive at follow-up (Table 4), we classified their infections as not school-related. In the first case, a secondary school student was retested because of a positive member of staff, but direct contact was excluded. Instead, the student's household member tested positive and developed symptoms a few days before the student. In the second case, a staff member had been at home to take care of a positive household member, and was tested positive at follow-up. Furthermore, five household members (four adults, one child) tested positive at follow-up. Except for the mentioned household member of the positive index student, the remaining four had a positive child in school 1 week before. For two of them, we assumed SARS-CoV-2 transmission via a positive index participant, and for two household members, this remained unclear. Consequently, we conservatively estimated the attack rate following 10 infections in eight school classes as $1.1 \%(95 \% \mathrm{Cl}$ : $0.3-2.9 ; 4 / 352$ persons with exposed index participant at cross-sectional assessment).

As to manifestation, two positive individuals were asymptomatic at retesting, whereas the others reported mainly cold-like symptoms (Table 4).

\section{Comparison of SARS-CoV-2 infected and non- infected participants}

SARS-CoV-2 infection was present in $4.7 \%, 1.9 \%$, and $1.0 \%$ of classes located in the low, medium, and high socioeconomical strata, respectively (high vs low; $\mathrm{OR}=4.71 ; 95 \% \mathrm{Cl}:$ 0.82-48.18; Table 5). Almost nine in 10 index participants stated to wear a facemask often or always at school, and their infection prevalence was $1.4 \%$. Of those who wore masks never to sometimes, $14.3 \%$ tested positive $(O R=11.38 ; 95 \%$ $\mathrm{Cl}: 2.28-59.64)$. Similarly, eight of the 16 non-affected classes and one of the eight affected classes reported a facemask obligation in classroom. While contact to a suspected or confirmed COVID-19 case in school did not confer increased odds of infection, such contacts outside school tended to do so (infection prevalence: 8.3\%; OR = 3.52; 95\% Cl: 0.56-16.27). Lastly, infection tended to be more common in those who reported to walk to school (without other means of transport; prevalence, 8.2\%; OR = 3.84; 95\% Cl: 0.76-16.82).

Among household members, infection was more prevalent in the low compared with the high socioeconomical stratum $(\mathrm{OR}=12.37 ; 95 \% \mathrm{Cl}: 2.68-114.84)$, and in those who had contact to a suspected or confirmed case outside of work or school (OR $=5.76 ; 95 \% \mathrm{Cl}$ : 1.37-21.96; data not shown).

\section{Discussion}

Our results from schools during peaking SARS-CoV-2 transmission in November 2020 in Berlin are: in one third of the classes, one or two infections were detected, mostly asymptomatic. Connected household members in $2.3 \%$ were also infected; a school-related origin of infection was unlikely in two third of cases. No secondary infections occurred in the affected classes within 1 week. The attack rate in households connected to positive classes was $1.1 \%$. Infection prevalence in school was increased in case of rare wearing of facemask in school, walking to school, low socioeconomical stratum, and case-contacts beyond school.

The SARS-CoV-2 prevalence of $\mathbf{2 . 7} \%$ among students in our study exceeds results of similar studies in Germany and other highly affected European countries in that period. Amongmore than 2,500 students and staff in Saxony, Germany, in November 2020, $1.0 \%$ were infected with SARS-CoV-2; seroprevalence was $1.4 \%$ [20]. A concurrent study in Austrian students reported $0.4 \%$ SARS-CoV-2 prevalence [21], while in more than 100 English schools, $1.2 \%$ of students and $1.3 \%$ of staff were infected [5]. During data collection, the 7-day incidence in Berlin among those aged 15-19-years exceeded that of younger ages. This accords with higher infection figures in secondary than in primary school students [4], but contrasts our findings. We cannot exclude an incidental finding; differences in hygiene and distancing might also be involved [22], e.g., mask wearing was not mandatory at primary schools. Only one of 140 attending school staff was infected at cross-sectional testing. This is in line with data from England, where SARS-CoV-2 infection was present in $0.4 \%$ of teachers, similar to other professions, arguing against increased infection risks among school staff [5]. More than half of all participants reported mainly cold-like symptoms in the preceding 2 weeks, and about one in five on the test day. During study conduct, acute respiratory infections in Germany occurred at less than half the rate of previous years, probably due to enhanced hygiene measures [23]. However, surveyed symptoms are subjective, and health consciousness might increase during a pandemic, possibly causing overestimations. Yet, seven of 10 positively tested index participants were asymptomatic and would thus not have been identified by symptom-based testing. Similarly, five index participants had unknowingly developed antibodies. This stresses the benefit of routine testing in schools, which is now widely recommended and implemented [24].

When comparing SARS-CoV-2-uninfected and -infected index participants, the latter tended to attend school in the low socioeconomical stratum. School stratum was a rough proxy disregarding intra-district variability of education, occupation and income, but other research concurringly showed that social disadvantage and SARS-CoV-2 infection in students is associated [21]. Moreover, household infection clusters in our study occurred largely at low socioeconomical stratum. 
This may reflect household crowding with insufficient distancing and isolation possibilities promoting transmission. Increased infection prevalence was observed among those who inconsistently used facemasks in school. Wearing a facemask in school was not obligatory at that time, but many schools and classes nevertheless adhered to it. Prevalence was similar among participants with and without case-contacts in school, but with case-contacts outside of school, infection tended to be more prevalent. This corroborates findings from Mississippi, United States, where attending lessons was not found to be a risk factor for SARS-CoV-2 infection among students, but inconsistent mask wearing in school, close case-contacts outside the household, and social gatherings [11]. Lastly, prevalence was increased among those who walked to school. Lacking conclusive evidence, we suspect that grouping up with friends on the way to school was a possible reason.

In the connected households, SARS-CoV-2 prevalence of $2.3 \%$ was observed. Only for three of nine affected households, a school-link was assumed. At retesting, no school-related secondary infection was seen among students and staff of eight affected classes, despite ongoing exposure before quarantine. For the connected households, the attack rate was $1.1 \%$. This suggests that, even at high epidemic activity, attending lessons in school is not a major place of transmission if adequate IPC measures are implemented. So far, only few larger school outbreaks have occurred in Germany $[25,26]$. In the federal state of RhinelandPalatinate between August and December 2020, school surveillance yielded a secondary attack rate among primary contacts of around $1 \%$ [27]. A simultaneous investigation in neighbouring Hesse found an average secondary attack rate of $1.3 \%$ among contact persons in school [28]. Similarly, in Italy, there was a low prevalence in schools and low intra-school transmission in the study timeframe up to October 2020 [29].

These findings of a rather low level of transmission in the school context are difficult to reconcile with results indicating substantial effects of school closures. In observational data from the United States from early 2020, school closure was associated with significant declines in COVID-19 incidence and mortality [30], whereas in a systematic review of observational studies, effects of school closure are inconsistent [9]. Several modelling studies - usually from the first wave of the pandemic - suggest modest to substantial associations between school closures and incidence $[6,31]$. These include estimates of $40-60 \%$ reduced peak incidence [31], and of reducing the reproduction number by more than a third [6]. Moreover, school closures have been associated with an overall mobility reduction of $21.6 \%$ in Switzerland [32]. It remains difficult to disentangle the direct or indirect consequences of school closure from those of other non-pharmaceutical interventions, which were frequently implemented in parallel [30]. For example, school closures imply less mobility, but also substantial disruptions in daily routines, particularly for parents, and altered working conditions, childcare, and social contacts. Recent evidence shows that incidence in school and population are linked [5]. Similarly, our data suggest that most detected infections were not acquired in school. In class, students experience clear guidelines regarding preventive behaviour and respective enforcement. Such rules, e.g. wearing of facemasks and airing, may partially explain the rather low infection figures despite grouping in class. In contrast, during school closures, students possibly assemble in uncontrolled settings [33]. Conceivably, shutting down educational facilities brings about transmission reductions which are not directly attributable to attending classes and intra-school transmission, but to indirect consequences including parental behaviour. If that were true, pandemic mitigation measures would need to focus more strongly on indirect patterns, e.g. mandatory filtering masks in public, offering more frequent public transport to avoid overcrowding, and obligatory work from home wherever possible. However, there is a lack of information to delineate the respective impact on the COVID-19 pandemic during school closures. This is all the more regrettable when considering the many harmful consequences of this measure for children and society $[12,13]$.

The strengths of our study are random selection of schools across Berlin, school-based generation of empirical data rather than model-based estimates, inclusion of connected households, solid laboratory methods, and screening rather than symptom-based testing allowing for the detection of asymptomatic infections. The limitations of our study are a low number of outcome events and potential selection bias (voluntary participation). Comparative data on the prevalence of SARS-CoV-2 in the Berlin underage population are not available. Incomplete swabbing due to self-administration cannot completely be excluded despite illustrated instructions and PCR quality control including human RNase $P$ gene co-amplification.

\section{Conclusion}

SARS-CoV-2 infection activity in Berlin schools during peak transmission in November 2020 appeared to be low. Secondary transmission in class was absent, and in connected households, the attack rate was around $1 \%$. Based on our findings, we are cautiously optimistic that schooling itself does not necessarily lead to childto-child transmission or constitutes a central COVID-19 pandemic driver, provided that IPC measures are rigorously implemented. Our study is longitudinal and the continuation of our study will show whether this is true as the determinants of the pandemic change, including vaccination coverage, population immunity, relaxed or tightened lockdown, and viral mutations. Our findings do not exclude the possibility of school-based outbreaks, particularly at higher transmission or enhanced viral transmissibility. Repeat screening in schools to detect asymptomatic infections is justified by our data and should help reducing the infection burden [34]. As 
a prerequisite for further, tailored measures, deeper insight is needed into the fraction of infections attributable to being a school child as compared to school attendance itself.

\section{BECOSS Study Group}

Esna Bozkurt, Tanja Chylla, Melanie Bothmann, Esra Demirtas, llay Gülec, Verena Haack, Franziska Haniel, Philipp Horn, Sophia Kindzierski, Mandy Kollatzsch, Marco Kurzmann, Sascha Lieber, Elisabeth Linzbach, Frederike Peters, Heike Rössig, Rafael Santos de Oliveira, Julia Steger, Zümrüt Tuncer, Vanessa Voelskow, Christof Wiesmann

\section{Acknowledgements}

We thank the students, school staff and families for participation, and Charité - Universitätsmedizin Berlin and the Senate of Berlin for support.

Funding: The study was funded by the Senate of Berlin. The funder of the study had no role in study design, data collection, data analysis, data interpretation, or writing of the report.

\section{Conflict of interest}

TK states to have received outside of the submitted work personal fees from Eli Lily \& Company, Teva, TotalEnergies and the BMJ. All other authors declare that they have no conflict of interests.

\section{Authors' contributions}

ST, MT, FH, TK, JS, and FPM designed the study. ST, MT, WVL, $\mathrm{CH}, \mathrm{AvdH}, \mathrm{JK}, \mathrm{MAM}, \mathrm{AR}$, and FPM conducted on-site examinations, interviews, and sample collection. MS and FB did laboratory examinations. ST, WvL, FH, AvdH, JK, FPM, and TK were responsible for verifying underlying data, data management and analysis. CVK, VK, and JS organised staff allocation and logistics. BECOSS study group members did data collection. ST, WvL, FH, and FPM wrote the manuscript. All authors participated in drafting the article or revising it critically for intellectual content, and approved the final version.

\section{References}

1. Lee B, Raszka WV Jr. COVID-19 transmission and children: the child is not to blame. Pediatrics. 2020;146(2):e2020029736. https://doi.org/10.1542/peds.2020-004879 PMID: 32457212

2. Li X, Xu W, Dozier M, He Y, Kirolos A, Lang Z, et al. The role of children in the transmission of SARS- $\mathrm{CoV}_{2}$ : updated rapid review. J Glob Health. 2020;10(2):021101. https://doi. org/10.7189/jogh.10.0201101 PMID: 33312511

3. European Centre for Disease Prevention and Control (ECDC). COVID-19 in children and the role of school settings in transmission - second update. Stockholm: ECDC; 2021. Available from: https:// www.ecdc.europa.eu/en/publications-data/ children-and-school-settings-covid-19-transmission

4. Riley S, Walters CE, Wang H, Eales O, Ainslie KEC, Atchison C, et al. REACT-1 round 7 updated report: regional heterogeneity in changes in prevalence of SARS-CoV-2 infection during the second national COVID-19 lockdown in England. medRxiv. 2020:2020.12.15.20248244. https://doi.org/10.1101/2020.12. 15.20248244

5. Children's Task and Finish Group (TFC). Children's task and Finish group: update to 4 th Nov 2020 paper on children, schools and transmission. 17 December 2020. Helsinki: TFC. 2020. Available from: https://assets.publishing.service.gov. uk/government/uploads/system/uploads/attachment_data/ file/948617/s0998-tfc-update-to-4-november-2020-paper-onchildren-schools-transmission.pd

6. Brauner JM, Mindermann S, Sharma M, Johnston D, Salvatier J, Gavenčiak T, et al. Inferring the effectiveness of government interventions against COVID-19. Science. 2021;371(6531):eabd9338. https://doi.org/10.1126/science. abd9338 PMID: 33323424

7. Ismail SA, Saliba V, Lopez Bernal J, Ramsay ME, Ladhani SN. SARS-CoV-2 infection and transmission in educational settings: a prospective, cross-sectional analysis of infection clusters and outbreaks in England. Lancet Infect Dis. 2021;21(3):34453. https://doi.org/10.1016/S1473-3099(20)30882-3 PMID: 33306981

8. Viner RM, Russell SJ, Croker H, Packer J, Ward J, Stansfield $C$, et al. School closure and management practices during coronavirus outbreaks including COVID-19: a rapid systematic review. Lancet Child Adolesc Health. 2020;4(5):397-404. https://doi.org/10.1016/S2352-4642(20)30095-X PMID: 32272089

9. Walsh S, Chowdhury A, Braithwaite V, Russell S, Birch J, Ward J, et al. Do school closures reduce community transmission of COVID-19? A systematic review of observational studies. medRxiv. 2021:2021.01.02.2124914. https://doi. org/10.1101/2021.01.02.2124914

10. Heavey L, Casey G, Kelly C, Kelly D, McDarby G. No evidence of secondary transmission of COVID-19 from children attending school in Ireland, 2020. Euro Surveill. 2020;25(21):2000903. https://doi.org/10.2807/1560-7917.ES.2020.25.21.2000903 PMID: 32489179

11. Hobbs CV, Martin LM, Kim SS, Kirmse BM, Haynie L, McGraw S, et al. Factors associated with positive SARS-CoV-2 test results in outpatient health facilities and emergency departments among children and adolescents aged $<18$ years - Mississippi, September-November 2020. MMWR Morb Mortal Wkly Rep. 2020;69(50):1925-9. https://doi.org/10.15585/mmwr. mm6950e3 PMID: 33332298

12. Hanushek EA, Woessmann L. The economic impacts of learning losses. OECD education working papers, No. 225. Paris: OECD Publishing; 2020. Available from: https://www.oecd.org/ education/the-economic-impacts-of-learning-losses-21908d74en.htm

13. Masonbrink AR, Hurley E. Advocating for children during the COVID-19 school closures. Pediatrics. 2020;146(3):e20201440. https://doi.org/10.1542/peds.2020-1440 PMID: 32554517

14. Hommes F, van Loon W, Thielecke M, Abramovich I, Lieber S, Hammerich R, et al. SARS-CoV-2 infection, risk perception, behaviour and preventive measures at schools in Berlin, Germany, during the early post-lockdown phase: A cross-sectional study. Int J Environ Res Public Health. 2021;18(5):2739. https://doi.org/10.3390/ijerph18052739 PMID: 33800392

15. Robert Koch Institute (RKI). Coronavirus disease 2019 (COVID-19). Daily situation report of the Robert Koch Institute. Berlin: RKI; 2020. Available from: https://www.rki.de/DE/ Content/InfAZ/N/Neuartiges_Coronavirus/Situationsberichte/ Nov_2020/2020-11-16-en.pdf?_blob=publicationFile

16. Berliner Senatsverwaltung für Gesundheit und Soziales. Handlungsorientierter Sozialstrukturatlas Berlin 2013. [Action-oriented social structure atlas Berlin 2013]. Berlin: SenGPG; 2013. German. Available from: https://www.gesundheitliche-chancengleichheit.de/ handlungsorientierter-sozialstrukturatlas-berlin-2013

17. Senatsverwaltung für Bildung. Jugend und Familie (Sen BJF). Musterhygieneplan Corona für die Berliner Schulen (Aktualisierte Fassung vom 04.08.2020, Ergänzung zum Hygieneplan nach § 36 Infektionsschutzgesetz). [Model hygiene plan Corona for Berlin schools (updated version of 4 Aug 2020, supplement to the hygiene plan according to $\S 36$ Infection Protection Act)]. Berlin: Sen BJF; 2020. German. Available from: https://www.berlin.de/sen/bjf/ coronavirus/aktuelles/schrittweise-schuloeffnung/20200804 musterhygieneplan-corona-fuer-die-berliner-schulen.pdf

18. Harris PA, Taylor R, Minor BL, Elliott V, Fernandez M, O’Neal $L$, et al. The REDCap consortium: Building an international community of software platform partners. J Biomed Inform. 2019;95:103208. https://doi.org/10.1016/j.jbi.2019.103208 PMID: 31078660

19. R Core Team. R: A Language and Environment for Statistical Computing. Vienna: R Foundation for Statistical Computing; 2015. Available from: http://www.R-project.org/ (accessed Apr 14, 2021)

20. Jurkutat A, Meigen C, Vogel M, Kiess W. Studie zur Bewertung des Infektionsgeschehens mit SARS-CoV-2 bei Lehrkräften, Schülerinnen und Schülern in Sachsen. [Study to assess the incidence of infection with SARS-CoV-2 among teachers, students in Saxony]. Leipzig: Universität von Leipzig; 2020. German. Available from: https://home.uni-leipzig.de/ 
lifechild/wp-content/uploads/2020/12/Kurzbericht_nachNovembertests_final.pdf

21. Wagner $M$, Krause R, Willeit P, Lamprecht B. Ergebnisse der Erstuntersuchung der Schul-SARS-CoV-2-Monitoringstudie. [Results of the initial examination of the school SARS-CoV-2 monitoring study]. 2020. German. Available from: https:// www.jku.at/fileadmin/marketing/Presse_Savoy/News/2020/ November/JKU-Schul-SARS-CoV-2-Studie-Analyse-Abstract-PA. pdf

22. Ulyte A, Radtke T, Abela IA, Haile SR, Blankenberger J, Jung $R$, et al. Variation in SARS-CoV-2 seroprevalence in schoolchildren across districts, schools and classes. medRxiv. 2020:2020.09.18.20191254. https://doi.org/ https://doi.org/10 $.1101 / 2020.09 .18 .20191254$

23. Buda S, Dürrwald R, Biere B, Buchholz U, Tolksdorf K, Schilling J, et al. Influenza-Wochenbericht. Kalenderwoche 47 (14.11.2020 bis 20.11.2020). [Influenza weekly report. Calendar week 47 (14.11.2020 to 20.11.2020)]. Berlin: RIK; 2020. German. Available from: https://influenza.rki.de/ Wochenberichte/2020_2021/2020-47.pdf

24. Asgary A, Cojocaru MG, Najafabadi MM, Wu J. Simulating preventative testing of SARS-CoV-2 in schools: policy implications. BMC Public Health. 2021;21(1):125. https://doi. org/10.1186/s12889-020-10153-1 PMID: 33430832

25. Otte Im Kampe E, Lehfeld AS, Buda S, Buchholz U, Haas W. Surveillance of COVID-19 school outbreaks, Germany, March to August 2020. Euro Surveill. 2020;25(38):2001645. https:// doi.org/10.2807/1560-7917.ES.2020.25.38.2001645 PMID: 32975186

26. Ehrhardt J, Ekinci A, Krehl H, Meincke M, Finci I, Klein J, et al. Transmission of SARS-CoV-2 in children aged o to 19 years in childcare facilities and schools after their reopening in May 2020, Baden-Württemberg, Germany. Euro Surveill. 2020;25(36):2001587. https://doi.org/10.2807/1560-7917. ES.2020.25.36.2001587 PMID: 32914746

27. Zanger P. Secondary Attack Rate in Schools Surveillance, Rhineland-Palatinate (SARS-S). 2020. https://bm.rlp.de/ fileadmin/bm/Bildung/Corona/20201208_SARS-Secondary Attack_Rate_in_Schools_Surveillanc-Report_MW48_pub.pdf (accessed Jan 21, 2021)

28. Heudorf U, Steul K, Walczok A, Gottschalk R. COVID-19 in Schulen: Keine Pandemie-Treiber. [COVID-19 in schools: not pandemic drivers]. Dtsch Arztebl. 2020;117:A2505-8. German. Available from: https://www.aerzteblatt.de/archiv/217182/ COVID-19-in-Schulen-Keine-Pandemie-Treiber

29. Buonsenso D, De Rose C, Moroni R, Valentini P. SARS-CoV-2 infections in Italian schools: preliminary findings after 1 month of school opening during the second wave of the pandemic. Front Pediatr. 2021;8:615894. https://doi.org/10.3389/ fped.2020.615894 PMID: 33520898

30. Auger KA, Shah SS, Richardson T, Hartley D, Hall M, Warniment A, et al. Association Between Statewide School Closure and COVID-19 Incidence and Mortality in the US. JAMA. 2020;324(9):859-70. https://doi.org/10.1001/jama.2020.14348 PMID: 32745200

31. Zhang J, Litvinova M, Liang Y, Wang Y, Wang W, Zhao S, et al. Changes in contact patterns shape the dynamics of the COVID-19 outbreak in China. Science. 2020;368(6498):1481-6. https://doi.org/10.1126/science.abb8001 PMID: 32350060

32. Persson J, Parie JF, Feuerriegel S. Monitoring the COVID-19 epidemic with nationwide telecommunication data. arXiv. 2021:2101.02521V4. https://arxiv.org/abs/2101.02521V3

33. Brooks SK, Smith LE, Webster RK, Weston D, Woodland L, Hall I, et al. The impact of unplanned school closure on children's social contact: rapid evidence review. Euro Surveill. 2020;25(13):2000188. https://doi.org/10.2807/1560-7917. ES.2020.25.13.2000188 PMID: 32265006

34. Mina MJ, Parker R, Larremore DB. Rethinking Covid-19 test sensitivity - a strategy for containment. N Engl J Med. 2020;383(22):e120. https://doi.org/10.1056/NEJMp2025631 PMID: 32997903

License, supplementary material and copyright

This is an open-access article distributed under the terms of the Creative Commons Attribution (CC BY 4.0) Licence. You may share and adapt the material, but must give appropriate credit to the source, provide a link to the licence and indicate if changes were made.

Any supplementary material referenced in the article can be found in the online version.
This article is copyright of the authors or their affiliated institutions, 2021. 